\title{
O095: Isolation videoclip for visitors and patients
}

\author{
BS Ana ${ }^{*}$, CA Palos
}

From 2nd International Conference on Prevention and Infection Control (ICPIC 2013)

Geneva, Switzerland. 25-28 June 2013

HAI prevention and control applies to all settings of care. Screening and isolation of patients are tools that improve HAI prevention and control effectiveness. Awareness, understanding and compliance to different isolation precautions are a major problem for patients and visitors. This videoclip aims to introduce visitors and patients on the hospital isolation policy and procedures, explaining them in a simple and attractive way how to proceed, using a combination of avatar technology and real persons. Videoclips are a part of a global awareness and teaching materials on Infection Control and Prevention.

\section{Disclosure of interest}

None declared.

Published: 20 June 2013

Submit your next manuscript to BioMed Central and take full advantage of:

- Convenient online submission

- Thorough peer review

- No space constraints or color figure charges

- Immediate publication on acceptance

- Inclusion in PubMed, CAS, Scopus and Google Scholar

- Research which is freely available for redistribution

\section{Biomed Central}

